Received 18.03.2017

Reviewed 12.04.2017

Accepted 18.04.2017

A - study design

B - data collection

C - statistical analysis

D - data interpretation

$\mathbf{E}$ - manuscript preparation

F - literature search

\title{
The size of an external patchwork of fields as an indicator of urgency for land consolidation and exchange on the example of the commune of Lesko
}

\author{
Przemyslaw LEŃ ${ }^{\text {ABCDEF } \bowtie}$
}

University of Life Sciences in Lublin, Faculty of Production Engineering, ul. Leszczyńskiego 7, 20-069 Lublin, Poland; e-mail: przemysław.len@up.lublin.pl

For citation: Leń P. 2017. The size of an external patchwork of fields as an indicator of urgency for land consolidation and exchange on the example of the commune of Lesko. Journal of Water and Land Development. No. 33 p. 107114. DOI: 10.1515/jwld-2017-0025.

\begin{abstract}
The patchwork of plots is one of the major factors that have a negative impact on both the organization and the level of agricultural production. Excessive fragmentation reduces the intensity of the work and increases the cost of agricultural production, thereby generating lower and lower income.

This paper presents data regarding the share of farmland belonging to non-resident owners in the commune of Lesko, which encompasses 15 cadastral communities. The data studied include the number of plots, their surface areas, and the number of owners. The study was conducted using checkerboard matrix tables which allow one to determine the share of farmland owned by local and out-of-village non-residents. An approach like this allows one to establish a program of exchange of land between these two groups of owners and to eliminate the problematic patchwork of land ownership through land exchange and consolidation.
\end{abstract}

Key words: land exchange and consolidation, non-resident owners, patchwork of land ownership, rural areas

\section{INTRODUCTION}

Different regions of Poland are characterized by different features which affect their economic development. In the Podkarpackie Province (Voivodeship), rural areas show a very low level of agricultural development. Large fragmentation of land-holdings and the type of soil found in this area make land cultivation more costly than in other regions of the country. The whole situation is exacerbated by extensive scattering of individual holdings. To amend the spatial structure of rural areas, exchange and consolidation programs should be developed for highly fragmented and scattered farmland, which would facilitate land cultivation in such areas, make it cheaper, and this way improve the quality of life of their inhabitants.

The aim of this article was to analyse the external patchwork of fields belonging to individual land holdings in the villages of the commune of Lesko, located in the northern part of the Lesko county (district leski) in the Podkarpackie Province. The area of land belonging to local and out-of-village non-resident owners was determined for each village of the study area. As a last stage of the study, the degree of fragmentation of farmland in the villages of the investigated community was established using checkerboard matrix tables.

\section{CHARACTERISTICS OF THE PATCHWORK PATTERN OF LAND OWNERSHIP}

Fragmentation of land is a problem in most countries. It adversely affects agriculture by reducing production efficiency and enforcing inefficient allocation of resources (labour and capital), which results in increased costs and difficulties in modernizing agriculture [DUDZIŃSKA 2012]. In land management, a pattern of scattered parcels (cadastral plots) is referred to 
as a patchwork (a checkerboard) of land ownership. Both in Poland and in other countries, checkerboarding (which gives rise to a patchwork pattern of land ownership) is usually a result of long-term historical processes. The Polish countryside occupies more than 93\% of the area of our country [BALAWEJDER et al. 2015]. About 3 million hectares of agricultural land in Poland are characterised by a faulty pattern of land ownership [BALAWEJDER, NOGA 2016]. Factors that have contributed to this situation include economic and legal aspects of agriculture as well as socioeconomic conditions [NoGA 1977; 1985a; 1985b]. From the point of view of administrative boundaries, there are two groups of patchwork patterns of land ownership, an internal and an external patchwork. The concept of a patchwork of fields was introduced into Polish agricultural geodesy in 1907 by Kocent-Zieliński, who defined it as an area of land belonging to one village, in which land owned by an individual farmer is not located in one piece next to the house, but is fragmented into a number of (usually narrow and long) parcels scattered over a large space and intermingled with parcels belonging to other owners [KOCENT-ZIELIŃSKI 1907].

Research on the external patchwork of farmland belonging to individual holdings in south-eastern Poland (Podkarpackie Province) has revealed serious defects in the structure of land ownership in this region. In the villages of Brzozów county (district brzozowski), out-of-village non-resident owners are in the possession of 7146.8 ha of land divided into 23394 cadastral plots. The plots are in the hands of 9341 owners who live both in the investigated area, as well as beyond its boundaries [LEŃ 2009; 2012]. In the village of Będziemyśl, located in Ropczyce-Sędziszów county (district ropczycko-sędziszowski), land belonging to out-of-village non-resident owners occupies an area of 139.87 hectares, representing $26.67 \%$ of the total area of the village; this land is divided into 301 plots $(20.01 \%$ of plots in the village) [LEŃ et al. 2015b]. In the village of Olszanica, located in Lesko county (district leski), 306 cadastral plots (24.3\% of privately owned parcels) with an area of
149.53 ha (26.6\% of farmland in individual holdings) belongs to 154 owners from outside the study area (26. 6\% of all owners) [LEŃ et al. 2015a]. In the village of Konieczkowa in Strzyżów county (district strzyżowski), 222 out-of-village owners have 483 cadastral plots $(15.8 \%)$ with an area of 195.20 hectares, which constitute $17.7 \%$ of the total area of the village. In the village of Lutcza, in turn, $19.9 \%$ of all plots are owned by out-of-village non-resident owners (1361 cadastral plots with an area of 531.93 ha, ie. $18.8 \%$ of the total area of the village) [LEŃ et al. 2016].

Nowadays, it is recommended that measures be taken to eliminate both internal and external patchworks of farmland. Two such agricultural land management measures are land consolidation and land exchange.

\section{MATERIALS AND METHODS}

Data for the research in the form of a descriptive and graphical part of the excerpts from the land register were taken from the cadastral estate of the district office in Lesko. The analysis showed that out of 10228 plots belonging to individual holdings, 3030 parcels, i.e., $29.6 \%$ of the total number of plots, were owned by out-of-village non-resident owners. These plots occupied an area of 3347.84 ha, i.e. $37.01 \%$ of the total area of farmland belonging to individual holdings. The plots were owned by 1641 people who lived both in the investigated area as well as beyond its boundaries [LEŃ 2009; 2012].

As seen in Table 1, the largest area of land in the village of Lesko (270.8702 hectares, $61.3 \%$ of the total area of privately-owned farmland) is owned by outof-village non-residents. A high percentage of land belonging to out-of-village non-residents was recorded in the villages of Manasterzec (268.7669 ha, i.e. $52.2 \%$ of land in the private sector), Dziurdziów (191.2490 ha, 54.1\%), and Huzele (145.0285 ha, $58.8 \%$ ). The smallest contribution of land in the hands of out-of-village non-residents was found in Bachlawa (34.0494 ha).

Table 1. Data regarding land ownership by out-of-village non-residents in the commune of Lesko

\begin{tabular}{|c|c|c|c|c|c|c|c|c|c|c|c|c|c|c|c|}
\hline \multirow{3}{*}{ Name of village } & \multirow{3}{*}{$\begin{array}{c}\text { Area of pri- } \\
\text { vately owned } \\
\text { farmland } \\
\text { ha }\end{array}$} & \multirow{3}{*}{$\begin{array}{l}\text { Number of } \\
\text { privately } \\
\text { owned plots }\end{array}$} & \multirow{3}{*}{$\begin{array}{c}\text { Number } \\
\text { of } \\
\text { owners }\end{array}$} & \multicolumn{6}{|c|}{$\begin{array}{l}\text { Farmland belonging to out-of-village non-resident owners } \\
\text { residing in the area of the commune }\end{array}$} & \multicolumn{6}{|c|}{$\begin{array}{l}\text { Farmland belonging to out-of-village non-resident owners } \\
\text { residing in Lesko county }\end{array}$} \\
\hline & & & & \multicolumn{2}{|c|}{ owners } & \multicolumn{2}{|c|}{ plots } & \multicolumn{2}{|c|}{ area } & \multicolumn{2}{|c|}{ owners } & \multicolumn{2}{|c|}{ plots } & \multicolumn{2}{|c|}{ area } \\
\hline & & & & number & $\%$ & number & $\%$ & ha & $\%$ & number & $\%$ & number & $\%$ & ha & $\%$ \\
\hline Bachlawa & 129.6348 & 220 & 112 & 17 & 15.2 & 31 & 14.1 & 21.34 & 16.5 & 6 & 5.4 & 7 & 3.2 & 5.445 & 4.2 \\
\hline Bezmiechowa Dolna & 240.8211 & 677 & 210 & 37 & 17.6 & 86 & 12.7 & 25.52 & 10.6 & 4 & 1.9 & 12 & 1.8 & 3.455 & 1.4 \\
\hline Bezmiechowa Górna & 316.9037 & 394 & 159 & 40 & 25.2 & 67 & 17.0 & 54.08 & 17.1 & 7 & 4.4 & 17 & 4.3 & 10.700 & 3.4 \\
\hline Dziurdziów & 353.5109 & 491 & 143 & 27 & 18.9 & 52 & 10.6 & 24.93 & 7.1 & 7 & 4.9 & 24 & 4.9 & 11.930 & 3.4 \\
\hline Glinne & 162.8883 & 352 & 158 & 27 & 17.1 & 47 & 13.4 & 17.93 & 11.0 & 16 & 10.1 & 31 & 8.8 & 10.210 & 6.3 \\
\hline Hoczew & 488.7827 & 828 & 355 & 35 & 9.9 & 48 & 5.8 & 24.78 & 5.1 & 22 & 6.2 & 41 & 5.0 & 28.560 & 5.8 \\
\hline Huzele & 246.4818 & 828 & 337 & 76 & 22.6 & 129 & 15.6 & 86.15 & 35.0 & 8 & 2.4 & 14 & 1.7 & 3.156 & 1.3 \\
\hline Jankowce & 388.1461 & 1146 & 337 & 59 & 17.5 & 133 & 11.6 & 55.08 & 14.2 & 19 & 5.6 & 50 & 4.4 & 14.520 & 3.7 \\
\hline Lesko & 441.5178 & 2220 & 1342 & 331 & 24.7 & 575 & 25.9 & 202.40 & 45.8 & 28 & 2.1 & 35 & 1.6 & 4.617 & 1.1 \\
\hline Lączki & 83.6214 & 271 & 171 & 65 & 38.0 & 103 & 38.0 & 33.63 & 40.2 & 10 & 5.9 & 14 & 5.2 & 1.972 & 2.4 \\
\hline Łukawica & 114.1087 & 527 & 166 & 25 & 15.1 & 40 & 7.6 & 11.57 & 10.1 & 5 & 3.0 & 12 & 2.3 & 4.600 & 4.0 \\
\hline Manasterzec & 514.6333 & 438 & 256 & 56 & 21.9 & 80 & 18.3 & 67.35 & 13.1 & 5 & 2.0 & 11 & 2.5 & 11.840 & 2.3 \\
\hline Postołów & 193.4532 & 284 & 133 & 15 & 11.3 & 48 & 16.9 & 55.92 & 28.9 & 4 & 3.0 & 4 & 1.4 & 2.132 & 1.1 \\
\hline Średnia Wieś & 728.1847 & 1323 & 517 & 39 & 7.5 & 93 & 7.0 & 51.46 & 7.1 & 16 & 3.1 & 24 & 1.8 & 10.490 & 1.4 \\
\hline Weremień & 137.4525 & 229 & 100 & 15 & 15.0 & 26 & 11.4 & 14.04 & 10.2 & 3 & 3.0 & 5 & 2.2 & 1.470 & 1.1 \\
\hline Total & 4540.1410 & 10228 & 4496 & 864 & 19.2 & 1558 & 15.2 & 746.10 & 16.4 & 160 & 3.6 & 301 & 2.9 & $\begin{array}{l}125.100 \\
\end{array}$ & 2.8 \\
\hline
\end{tabular}

Source: own study based on Register of Land and Buildings (EGiB). 
The largest numbers of out-of-village non-residents own land in Lesko, Huzele, Manasterzec, Jankowce, and Łączki $(40.2 \%, 40.4 \%, 48.4 \%, 33.5 \%$ and $66.1 \%$ of the total number of out-of-village nonresidents in the commune, respectively).

The patchwork of land in the study area was created as a result of both land inheritance and migration of people to cities. These activities contributed to the defective spatial structure of the villages in the commune of Lesko. For over a decade now, plots have been purchased in those villages by city dwellers for recreation and leisure purposes as well as an investment of capital.

The impact of towns and cities, which are administrative, service, industrial and cultural-educational centres, is reflected in the number and area of plots belonging to urban inhabitants. As illustrated by data in Table 2, the largest number of out-of-village non-resident owners in the analysed area are inhabitants of the town of Lesko, the seat of commune authorities. 268 owners from the town of Lesko possess 514 parcels with a total area of 416.0620 ha.

The numbers of owners and the areas of land belonging to them are quite varied and depend on the location of a given village in the commune of Lesko. A second town which exerts an impact on land ownership in the investigated area is the town of Sanok. Data showing what contribution of land in the commune of Lesko is owned by inhabitants of Sanok are given in Table 3. It follows from the analysis of these data that the largest numbers of owners from Sanok have plots in the commune town of Lesko, and the villages of Manastarzec and Postołów. In the remaining villages of the investigated commune, the number of plots belonging to out-of-village non-resident owners depends on the distance from urban centres (the larger the distance, the lower the number of non-resident owners from towns) and the available transport network.

Another town which has an impact on the structure of land ownership in the investigated area is Zagórz, a seat of commune authorities, which is an administrative part of Sanok county (district sanocki).
As data in Table 4 show, 26 owners from Zagórz have 50 cadastral plots with a total area of 59.0159 hectares. They own land in 11 villages of the commune of Lesko.

The structure of land ownership in the commune of Lesko is also affected by the vicinity of larger cities, Rzeszów and Kraków, which are administrative, service, industrial, cultural and scientific centres and capitals of provinces (Tab. 5 and 6). The spatial distribution of the numbers of owners from Rzeszów and Kraków and the areas of farmland in their possession are quite varied in the different villages of the investigated commune.

Apart from land belonging to out-of-village nonresidents, there are also plots in the study area which are in the hands of local non-resident owners. The area occupied by those plots was calculated using checkerboard matrix tables. As data in Table 7 indicate, local non-residents own 619.7973 hectares of land, i.e., $13.7 \%$ of the total area of privately owned land in the commune. This area is divided into 1,125 parcels owned by 625 people.

The contribution of owners, plot areas and numbers of plots differ from village to village, which is due to the natural conditions associated with the geographical location of the commune, its transport networks, and the distance from Lesko, the administrative, service and cultural centre of the commune. A map showing the distribution of non-resident-owned land by area (size) is given in Figure 1.

\section{RESULTS AND DISCUSSION}

The application of checkerboard matrix tables in the analysis and evaluation of patchworks of land ownership [NOGA 1985a] allows one to create matrices of any degree for one or many villages or communes. The size of a matrix depends on the extent of the patchwork of fields (what area it covers). To obtain information necessary to create a matrix, the area to be covered by the study has to be specified first. Then, data regarding the area of arable land, number of plots and number of non-resident owners have to

\begin{tabular}{|c|c|c|c|c|c|c|c|c|c|c|c|c|c|c|c|c|c|}
\hline \multicolumn{6}{|c|}{$\begin{array}{l}\text { Farmland belonging to out-of-village non-resident owners } \\
\text { residing in towns and cities }\end{array}$} & \multicolumn{6}{|c|}{ Remaining land owned by non-residents } & \multicolumn{6}{|c|}{ Farmland belonging to out-of-village non-resident owners } \\
\hline \multicolumn{2}{|c|}{ owners } & \multicolumn{2}{|c|}{ plots } & \multicolumn{2}{|c|}{ area } & \multicolumn{2}{|c|}{ owners } & \multicolumn{2}{|c|}{ plots } & \multicolumn{2}{|c|}{ area } & \multicolumn{2}{|c|}{ owners } & \multicolumn{2}{|c|}{ plots } & \multicolumn{2}{|c|}{ area } \\
\hline number & $\%$ & number & $\%$ & ha & $\%$ & number & $\%$ & number & $\%$ & ha & $\%$ & number & $\%$ & number & $\%$ & ha & $\%$ \\
\hline 0 & 0.0 & 0 & 0.0 & 0 & 0.0 & 6 & 5.4 & 8 & 3.6 & 7.2603 & 5.6 & 29 & 25.9 & 46 & 20.9 & 34.0494 & 26.3 \\
\hline 6 & 2.9 & 7 & 1.0 & 5.7742 & 2.4 & 19 & 9.0 & 49 & 7.2 & 22.8266 & 9.5 & 66 & 31.4 & 154 & 22.7 & 57.5717 & 23.9 \\
\hline 12 & 7.6 & 16 & 4.1 & 12.2028 & 3.9 & 13 & 8.2 & 32 & 8.1 & 40.9675 & 12.9 & 72 & 45.3 & 132 & 33.5 & 117.9533 & 37.2 \\
\hline 4 & 2.8 & 6 & 1.2 & 8.3837 & 2.4 & 18 & 12.6 & 91 & 18.5 & 146.0048 & 41.3 & 56 & 39.2 & 173 & 35.2 & 191.249 & 54.1 \\
\hline 2 & 1.3 & 5 & 1.4 & 1.6000 & 1.0 & 17 & 10.8 & 32 & 9.1 & 21.0800 & 12.9 & 62 & 39.2 & 115 & 32.7 & 50.8159 & 31.2 \\
\hline 10 & 2.8 & 14 & 1.7 & 6.4218 & 1.3 & 24 & 6.8 & 71 & 8.6 & 44.3598 & 9.1 & 91 & 25.6 & 174 & 21.0 & 104.1237 & 21.3 \\
\hline 12 & 3.6 & 35 & 4.2 & 14.1051 & 5.7 & 40 & 11.9 & 91 & 11.0 & 41.6152 & 16.9 & 136 & 40.4 & 269 & 32.5 & 145.0285 & 58.8 \\
\hline 3 & 0.9 & 5 & 0.4 & 4.4165 & 1.1 & 32 & 9.5 & 51 & 4.5 & 26.0260 & 6.7 & 113 & 33.5 & 239 & 20.9 & 100.0423 & 25.8 \\
\hline 58 & 4.3 & 82 & 3.7 & 10.6553 & 2.4 & 123 & 9.2 & 210 & 9.5 & 53.2447 & 12.1 & 540 & 40.2 & 902 & 40.6 & 270.8702 & 61.3 \\
\hline 12 & 7.0 & 20 & 7.4 & 5.3160 & 6.4 & 26 & 15.2 & 30 & 11.1 & 13.0445 & 15.6 & 113 & 66.1 & 167 & 61.6 & 53.9630 & 64.5 \\
\hline 11 & 6.6 & 21 & 4.0 & 4.6551 & 4.1 & 16 & 9.6 & 53 & 10.1 & 13.7021 & 12.0 & 57 & 34.3 & 126 & 23.9 & 34.5245 & 30.3 \\
\hline 26 & 10.2 & 56 & 12.8 & 78.3409 & 15.2 & 37 & 14.5 & 51 & 11.6 & 111.2407 & 21.6 & 124 & 48.4 & 198 & 45.2 & 268.7669 & 52.2 \\
\hline 23 & 17.3 & 36 & 12.7 & 12.7899 & 6.6 & 7 & 5.3 & 8 & 2.8 & 16.7491 & 8.7 & 49 & 36.8 & 96 & 33.8 & 87.5862 & 45.3 \\
\hline 5 & 1.0 & 6 & 0.5 & 3.6252 & 0.5 & 20 & 3.9 & 45 & 3.4 & 36.4457 & 5.0 & 80 & 15.5 & 168 & 12.7 & 102.0227 & 14.0 \\
\hline 1 & 1.0 & 2 & 0.9 & 0.2238 & 0.2 & 17 & 17.0 & 38 & 16.6 & 19.8742 & 14.5 & 36 & 36.0 & 71 & 31.0 & 35.6086 & 25.9 \\
\hline 185 & 4.1 & 311 & 3.0 & 168.5103 & 3.7 & 415 & 9.2 & 860 & 8.4 & 614.4412 & 13.5 & 1624 & 36.1 & 3030 & 29.6 & 1654.176 & 36.4 \\
\hline
\end{tabular}


Table 2. Farmland belonging to out-of-village non-resident owners from the town of Lesko

\begin{tabular}{|c|c|c|c|c|c|c|c|c|c|}
\hline \multirow{3}{*}{ Name of village } & \multirow{3}{*}{$\begin{array}{c}\text { Area of privately } \\
\text { owned farmland } \\
\text { ha }\end{array}$} & \multirow{3}{*}{$\begin{array}{c}\text { Number } \\
\text { of privately } \\
\text { owned plots }\end{array}$} & \multirow{3}{*}{$\begin{array}{l}\text { Number } \\
\text { of owners }\end{array}$} & \multicolumn{6}{|c|}{ Farmland belonging to out-of-village owners } \\
\hline & & & & \multicolumn{2}{|c|}{ owners } & \multicolumn{2}{|c|}{ plots } & \multicolumn{2}{|c|}{ area } \\
\hline & & & & number & $\%$ & number & $\%$ & ha & $\%$ \\
\hline Bachlawa & 129.6348 & 220 & 112 & 2 & 1.8 & 2 & 0.9 & 2.7101 & 2.1 \\
\hline Bezmiechowa Dolna & 240.8211 & 677 & 210 & 27 & 12.9 & 71 & 10.5 & 19.2749 & 8.0 \\
\hline Bezmiechowa Górna & 316.9037 & 394 & 159 & 12 & 7.5 & 25 & 6.3 & 18.8864 & 6.0 \\
\hline Dziurdziów & 353.5109 & 491 & 143 & 9 & 6.3 & 21 & 4.3 & 6.3775 & 1.8 \\
\hline Glinne & 162.8883 & 352 & 158 & 14 & 8.9 & 27 & 7.7 & 12.7287 & 7.8 \\
\hline Hoczew & 488.7827 & 828 & 355 & 12 & 3.4 & 17 & 2.1 & 5.6185 & 1.1 \\
\hline Huzele & 246.4818 & 828 & 337 & 64 & 19.0 & 110 & 13.3 & 81.7872 & 33.2 \\
\hline Jankowce & 388.1461 & 1146 & 337 & 30 & 8.9 & 61 & 5.3 & 23.1570 & 6.0 \\
\hline Łączki & 83.6214 & 271 & 171 & 45 & 26.3 & 76 & 28.0 & 19.7216 & 23.6 \\
\hline Łukawica & 114.1087 & 527 & 166 & 11 & 6.6 & 18 & 3.4 & 6.2000 & 5.4 \\
\hline Manasterzec & 514.6333 & 438 & 256 & 19 & 7.4 & 24 & 5.5 & $\begin{array}{l}17.3140 \\
\end{array}$ & 3.4 \\
\hline Postołów & 193.4532 & 284 & 133 & 11 & 8.3 & 38 & 13.4 & 54.2340 & 28.0 \\
\hline Średnia Wieś & 728.1847 & 1323 & 517 & 3 & 0.6 & 4 & 0.3 & 0.7291 & 0.1 \\
\hline Weremień & 137.4525 & 229 & 100 & 9 & 9.0 & 20 & 8.7 & 12.0613 & 8.8 \\
\hline Total & 4098.6232 & 8008 & 3154 & 268 & 8.5 & 514 & 6.4 & 416.0620 & 10.2 \\
\hline
\end{tabular}

Source: own study based on data of Register of Land and Buildings (EGiB).

Table 3. Farmland belonging to out-of-village non-resident owners from the town of Sanok

\begin{tabular}{|c|c|c|c|c|c|c|c|c|c|}
\hline \multirow{3}{*}{ Name of village } & \multirow{3}{*}{$\begin{array}{c}\text { Area of privately } \\
\text { owned farmland } \\
\text { ha }\end{array}$} & \multirow{3}{*}{$\begin{array}{c}\text { Number } \\
\text { of privately } \\
\text { owned plots }\end{array}$} & \multirow{3}{*}{$\begin{array}{c}\text { Number of } \\
\text { owners }\end{array}$} & \multicolumn{6}{|c|}{ Farmland belonging to out-of-village owners } \\
\hline & & & & \multicolumn{2}{|c|}{ owners } & \multicolumn{2}{|c|}{ plots } & \multicolumn{2}{|c|}{ area } \\
\hline & & & & number & $\%$ & number & $\%$ & ha & $\%$ \\
\hline Bachlawa & 129.6348 & 220 & 112 & 0 & 0.0 & 0 & 0.0 & 0.0000 & 0.0 \\
\hline Bezmiechowa Dolna & 240.8211 & 677 & 210 & 2 & 1.0 & 3 & 0.4 & 1.5042 & 0.6 \\
\hline Bezmiechowa Górna & 316.9037 & 394 & 159 & 5 & 3.1 & 6 & 1.5 & 6.1471 & 1.9 \\
\hline Dziurdziów & 353.5109 & 491 & 143 & 1 & 0.7 & 2 & 0.4 & 1.5866 & 0.4 \\
\hline Glinne & 162.8883 & 352 & 158 & 1 & 0.6 & 2 & 0.6 & 0.6800 & 0.4 \\
\hline Hoczew & 488.7827 & 828 & 355 & 5 & 1.4 & 6 & 0.7 & 3.3917 & 0.7 \\
\hline Huzele & 246.4818 & 828 & 337 & 5 & 1.5 & 12 & 1.4 & 10.6200 & 4.3 \\
\hline Jankowce & 388.1461 & 1146 & 337 & 2 & 0.6 & 2 & 0.2 & 0.1865 & 0.0 \\
\hline Lesko & 441.5178 & 2220 & 1342 & 30 & 2.2 & 40 & 1.8 & 5.3524 & 1.2 \\
\hline Łączki & 83.6214 & 271 & 171 & 6 & 3.5 & 8 & 3.0 & 2.7556 & 3.3 \\
\hline Łukawica & 114.1087 & 527 & 166 & 6 & 3.6 & 16 & 3.0 & 3.5400 & 3.1 \\
\hline Manasterzec & 514.6333 & 438 & 256 & 20 & 7.8 & 39 & 8.9 & 34.0927 & 6.6 \\
\hline Postołów & 193.4532 & 284 & 133 & 13 & 9.8 & 24 & 8.5 & 6.0873 & 3.1 \\
\hline Średnia Wieś & 728.1847 & 1323 & 517 & 3 & 0.6 & 3 & 0.2 & 1.7200 & 0.2 \\
\hline Weremień & 137.4525 & 229 & 100 & 0 & 0.0 & 0 & 0.0 & 0.0000 & 0.0 \\
\hline Total & 4540.1410 & 10228 & 4496 & 99 & 2.2 & 163 & 1.6 & 77.6641 & 1.7 \\
\hline
\end{tabular}

Source: own study based on data of Register of Land and Buildings (EGiB).

Table 4. Farmland belonging to out-of-village non-resident owners from the town of Zagórz

\begin{tabular}{|c|c|c|c|c|c|c|c|c|c|}
\hline \multirow{3}{*}{ Name of village } & \multirow{3}{*}{$\begin{array}{c}\text { Area of privately } \\
\text { owned farmland } \\
\text { ha }\end{array}$} & \multirow{3}{*}{$\begin{array}{l}\text { Number of } \\
\text { privately } \\
\text { owned plots }\end{array}$} & \multirow{3}{*}{$\begin{array}{c}\text { Number of } \\
\text { owners }\end{array}$} & \multicolumn{6}{|c|}{ Farmland belonging to out-of-village owners } \\
\hline & & & & \multicolumn{2}{|c|}{ owners } & \multicolumn{2}{|c|}{ plots } & \multicolumn{2}{|c|}{ area } \\
\hline & & & & number & $\%$ & number & $\%$ & ha & $\%$ \\
\hline Bachlawa & 129.6348 & 220 & 112 & 0 & 0.0 & 0 & 0.0 & 0.0000 & 0.0 \\
\hline Bezmiechowa Dolna & 240.8211 & 677 & 210 & 2 & 1.0 & 2 & 0.3 & 1.9773 & 0.8 \\
\hline Bezmiechowa Górna & 316.9037 & 394 & 159 & 3 & 1.9 & 3 & 0.8 & 3.9900 & 1.3 \\
\hline Dziurdziów & 353.5109 & 491 & 143 & 0 & 0.0 & 0 & 0.0 & 0.0000 & 0.0 \\
\hline Glinne & 162.8883 & 352 & 158 & 1 & 0.6 & 3 & 0.9 & 0.9200 & 0.6 \\
\hline Hoczew & 488.7827 & 828 & 355 & 1 & 0.3 & 1 & 0.1 & 0.7893 & 0.2 \\
\hline Huzele & 246.4818 & 828 & 337 & 1 & 0.3 & 8 & 1.0 & 1.2813 & 0.5 \\
\hline Jankowce & 388.1461 & 1146 & 337 & 0 & 0.0 & 0 & 0.0 & 0.0000 & 0.0 \\
\hline Lesko & 441.5178 & 2220 & 1342 & 3 & 0.2 & 3 & 0.1 & 0.8743 & 0.2 \\
\hline Łączki & 83.6214 & 271 & 171 & 1 & 0.6 & 3 & 1.1 & 0.8500 & 1.0 \\
\hline Łukawica & 114.1087 & 527 & 166 & 4 & 2.4 & 4 & 0.8 & 1.0751 & 0.9 \\
\hline Manasterzec & 514.6333 & 438 & 256 & 4 & 1.6 & 15 & 3.4 & 43.5247 & 8.5 \\
\hline Postołów & 193.4532 & 284 & 133 & 5 & 3.8 & 6 & 2.1 & 3.5101 & 1.8 \\
\hline Średnia Wieś & 728.1847 & 1323 & 517 & 0 & 0.0 & 0 & 0.0 & 0.0000 & 0.0 \\
\hline Weremień & 137.4525 & 229 & 100 & 1 & 1.0 & 2 & 0.9 & 0.2238 & 0.2 \\
\hline Total & 4540.1410 & 10228 & 4496 & 26 & 0.6 & 50 & 0.5 & 59.0159 & 1.3 \\
\hline
\end{tabular}

Source: own study based on data of Register of Land and Buildings (EGiB). 
Table 5. Farmland belonging to out-of-village non-resident owners from the city of Rzeszów

\begin{tabular}{|c|c|c|c|c|c|c|c|c|c|}
\hline \multirow{3}{*}{ Name of village } & \multirow{3}{*}{$\begin{array}{c}\text { Area of privately } \\
\text { owned farmland } \\
\text { ha }\end{array}$} & \multirow{3}{*}{$\begin{array}{c}\text { Number of } \\
\text { privately } \\
\text { owned plots }\end{array}$} & \multirow{3}{*}{$\begin{array}{c}\text { Number of } \\
\text { owners }\end{array}$} & \multicolumn{6}{|c|}{ Farmland belonging to out-of-village owners } \\
\hline & & & & \multicolumn{2}{|c|}{ owners } & \multicolumn{2}{|c|}{ plots } & \multicolumn{2}{|c|}{ area } \\
\hline & & & & number & $\%$ & number & $\%$ & ha & $\%$ \\
\hline Bachlawa & 129.6348 & 220 & 112 & 0 & 0.0 & 0 & 0.0 & 0.0000 & 0.0 \\
\hline Bezmiechowa Dolna & 240.8211 & 677 & 210 & 1 & 0.5 & 1 & 0.1 & 0.2504 & 0.1 \\
\hline Bezmiechowa Górna & 316.9037 & 394 & 159 & 2 & 1.3 & 2 & 0.5 & 0.3946 & 0.1 \\
\hline Dziurdziów & 353.5109 & 491 & 143 & 0 & 0.0 & 0 & 0.0 & 0.0000 & 0.0 \\
\hline Glinne & 162.8883 & 352 & 158 & 0 & 0.0 & 0 & 0.0 & 0.0000 & 0.0 \\
\hline Hoczew & 488.7827 & 828 & 355 & 3 & 0.8 & 5 & 0.6 & 2.1007 & 0.4 \\
\hline Huzele & 246.4818 & 828 & 337 & 2 & 0.6 & 2 & 0.2 & 0.2895 & 0.1 \\
\hline Jankowce & 388.1461 & 1146 & 337 & 1 & 0.3 & 3 & 0.3 & 4.2300 & 1.1 \\
\hline Lesko & 441.5178 & 2220 & 1342 & 16 & 1.2 & 23 & 1.0 & 2.8012 & 0.6 \\
\hline Łączki & 83.6214 & 271 & 171 & 1 & 0.6 & 5 & 1.8 & 0.4553 & 0.5 \\
\hline Łukawica & 114.1087 & 527 & 166 & 0 & 0.0 & 0 & 0.0 & 0.0000 & 0.0 \\
\hline Manasterzec & 514.6333 & 438 & 256 & 0 & 0.0 & 0 & 0.0 & 0.0000 & 0.0 \\
\hline Postołów & 193.4532 & 284 & 133 & 3 & 2.3 & 4 & 1.4 & 0.7825 & 0.4 \\
\hline Średnia Wieś & 728.1847 & 1323 & 517 & 1 & 0.2 & 2 & 0.2 & 1.7688 & 0.2 \\
\hline Weremień & 137.4525 & 229 & 100 & 0 & 0.0 & 0 & 0.0 & 0.0000 & 0.0 \\
\hline Total & 4540.1410 & 10228 & 4496 & 30 & 0.7 & 47 & 0.5 & 13.0730 & 0.3 \\
\hline
\end{tabular}

Source: own study based on data of Register of Land and Buildings (EGiB).

Table 6. Farmland belonging to out-of-village non-resident owners from the city of Kraków

\begin{tabular}{|c|c|c|c|c|c|c|c|c|c|}
\hline \multirow{3}{*}{ Name of village } & \multirow{3}{*}{$\begin{array}{c}\text { Area of privately } \\
\text { owned farmland } \\
\text { ha }\end{array}$} & \multirow{3}{*}{$\begin{array}{l}\text { Number of } \\
\text { privately } \\
\text { owned plots }\end{array}$} & \multirow{3}{*}{$\begin{array}{c}\text { Number of } \\
\text { owners }\end{array}$} & \multicolumn{6}{|c|}{ Farmland belonging to out-of-village owners } \\
\hline & & & & \multicolumn{2}{|c|}{ owners } & \multicolumn{2}{|c|}{ plots } & \multicolumn{2}{|c|}{ area } \\
\hline & & & & number & $\%$ & number & $\%$ & ha & $\%$ \\
\hline Bachlawa & 129.6348 & 220 & 112 & 0 & 0.0 & 0 & 0.0 & 0.0000 & 0.0 \\
\hline Bezmiechowa Dolna & 240.8211 & 677 & 210 & 1 & 0.5 & 1 & 0.1 & 2.0423 & 0.8 \\
\hline Bezmiechowa Górna & 316.9037 & 394 & 159 & 2 & 1.3 & 5 & 1.3 & 1.6711 & 0.5 \\
\hline Dziurdziów & 353.5109 & 491 & 143 & 3 & 2.1 & 4 & 0.8 & 6.7971 & 1.9 \\
\hline Glinne & 162.8883 & 352 & 158 & 0 & 0.0 & 0 & 0.0 & 0.0000 & 0.0 \\
\hline Hoczew & 488.7827 & 828 & 355 & 1 & 0.3 & 2 & 0.2 & 0.1401 & 0.0 \\
\hline Huzele & 246.4818 & 828 & 337 & 4 & 1.2 & 13 & 1.6 & 1.9143 & 0.8 \\
\hline Jankowce & 388.1461 & 1146 & 337 & 0 & 0.0 & 0 & 0.0 & 0.0000 & 0.0 \\
\hline Lesko & 441.5178 & 2220 & 1342 & 9 & 0.7 & 16 & 0.7 & 1.6274 & 0.4 \\
\hline Łączki & 83.6214 & 271 & 171 & 4 & 2.3 & 4 & 1.5 & 1.2551 & 1.5 \\
\hline Łukawica & 114.1087 & 527 & 166 & 1 & 0.6 & 1 & 0.2 & 0.0400 & 0.0 \\
\hline Manasterzec & 514.6333 & 438 & 256 & 2 & 0.8 & 2 & 0.5 & 0.7235 & 0.1 \\
\hline Postołów & 193.4532 & 284 & 133 & 2 & 1.5 & 2 & 0.7 & 2.4100 & 1.2 \\
\hline Średnia Wieś & 728.1847 & 1323 & 517 & 1 & 0.2 & 1 & 0.1 & 0.1364 & 0.0 \\
\hline Weremień & 137.4525 & 229 & 100 & 0 & 0.0 & 0 & 0.0 & 0.0000 & 0.0 \\
\hline Total & 4540.1410 & 10228 & 4496 & 30 & 0.7 & 51 & 0.5 & 18.7573 & 0.4 \\
\hline
\end{tabular}

Source: own study based on data of Register of Land and Buildings (EGiB).

Table 7. Farmland belonging to local non-resident owners

\begin{tabular}{|c|c|c|c|c|c|c|c|c|c|}
\hline \multirow{3}{*}{ Name of village } & \multirow{3}{*}{$\begin{array}{c}\text { Area of privately } \\
\text { owned farmland } \\
\text { ha }\end{array}$} & \multirow{3}{*}{$\begin{array}{l}\text { Number of } \\
\text { privately } \\
\text { owned plots }\end{array}$} & \multirow{3}{*}{$\begin{array}{c}\text { Number of } \\
\text { owners }\end{array}$} & \multicolumn{6}{|c|}{ Farmland belonging to local non-resident owners } \\
\hline & & & & \multicolumn{2}{|c|}{ owners } & \multicolumn{2}{|c|}{ plots } & \multicolumn{2}{|c|}{ area } \\
\hline & & & & number & $\%$ & number & $\%$ & ha & $\%$ \\
\hline Bachlawa & 129.6348 & 220 & 112 & 31 & 0.7 & 63 & 0.6 & 30.0823 & 0.7 \\
\hline Bezmiechowa Dolna & 240.8211 & 677 & 210 & 34 & 0.8 & 77 & 0.8 & 62.7344 & 1.4 \\
\hline Bezmiechowa Górna & 316.9037 & 394 & 159 & 7 & 0.2 & 7 & 0.1 & 2.4364 & 0.1 \\
\hline Dziurdziów & 353.5109 & 491 & 143 & 11 & 0.2 & 13 & 0.1 & 4.1177 & 0.1 \\
\hline Glinne & 162.8883 & 352 & 158 & 34 & 0.8 & 64 & 0.6 & 29.3143 & 0.7 \\
\hline Hoczew & 488.7827 & 828 & 355 & 56 & 1.3 & 92 & 0.9 & 53.1572 & 1.2 \\
\hline Huzele & 246.4818 & 828 & 337 & 28 & 0.6 & 47 & 0.5 & 16.9171 & 0.4 \\
\hline Jankowce & 388.1461 & 1146 & 337 & 42 & 0.9 & 72 & 0.7 & 42.8821 & 0.9 \\
\hline Lesko & 441.5178 & 2220 & 1342 & 268 & 6.0 & 514 & 5.0 & 280.8003 & 6.2 \\
\hline Łączki & 83.6214 & 271 & 171 & 15 & 0.3 & 20 & 0.2 & 6.5510 & 0.1 \\
\hline Łukawica & 114.1087 & 527 & 166 & 50 & 1.1 & 73 & 0.7 & 55.3848 & 1.2 \\
\hline Manasterzec & 514.6333 & 438 & 256 & 12 & 0.3 & 21 & 0.2 & 10.2299 & 0.2 \\
\hline Postołów & 193.4532 & 284 & 133 & 11 & 0.2 & 23 & 0.2 & 7.4642 & 0.2 \\
\hline Średnia Wieś & 728.1847 & 1323 & 517 & 18 & 0.4 & 30 & 0.3 & 13.2932 & 0.3 \\
\hline Weremień & 137.4525 & 229 & 100 & 8 & 0.2 & 9 & 0.1 & 4.4324 & 0.1 \\
\hline Total & 4540.1410 & 10228 & 4496 & 625 & 13.9 & 1125 & 11.0 & 619.7973 & 13.7 \\
\hline
\end{tabular}

Source: own study based on data of Register of Land and Buildings (EGiB). 


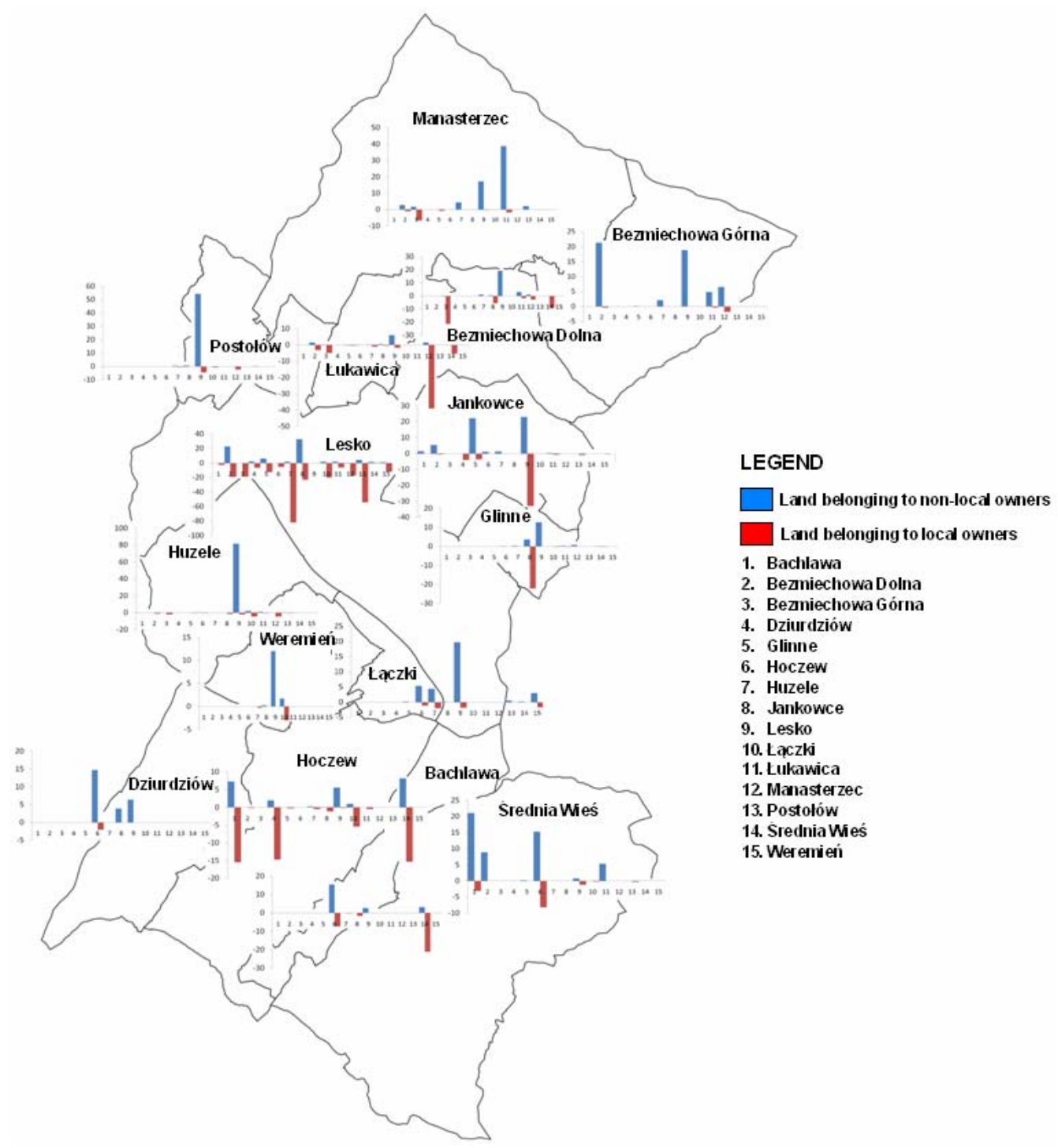

Fig. 1. Spatial distribution of non-resident-owned land by area (size); source: own study

Table 8. Matrix of the patchwork of farmland in the commune of Lesko

\begin{tabular}{|c|c|c|c|c|c|c|c|c|c|c|c|c|c|c|c|}
\hline $\begin{array}{l}\text { Name of ca- } \\
\text { dastral com- } \\
\text { munity }\end{array}$ & 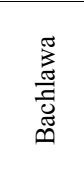 & \begin{tabular}{l}
3 \\
\multirow{N}{N}{} \\
0 \\
0 \\
0
\end{tabular} & 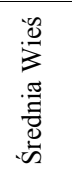 & 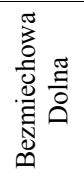 & 总 & 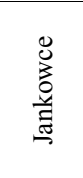 & 咅 & 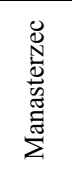 & 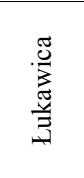 & $\stackrel{\stackrel{0}{N}}{\stackrel{\Xi}{\Xi}}$ & 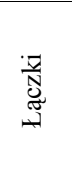 & 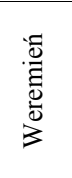 & 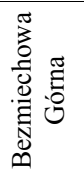 & 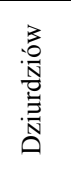 & $\begin{array}{l}3 \\
\frac{3}{0} \\
0 \\
0 \\
0 \\
0\end{array}$ \\
\hline Bachlawa & 0.00 & 15.45 & 3.19 & 0.00 & 2.71 & 0.00 & 0.00 & 0.00 & 0.00 & 0.00 & 0.00 & 0.00 & 0.00 & 0.00 & 0.00 \\
\hline Hoczew & 7.32 & 0.00 & 8.24 & 0.00 & 5.62 & 0.17 & 0.00 & 0.00 & 0.00 & 0.30 & 1.10 & 0.00 & 0.00 & 2.04 & 0.00 \\
\hline Średnia Wieś & 21.08 & 15.30 & 0.00 & 8.86 & 0.73 & 0.00 & 0.19 & 0.00 & 5.31 & 0.00 & 0.00 & 0.00 & 0.00 & 0.00 & 0.00 \\
\hline $\begin{array}{l}\text { Bezmiechowa } \\
\text { Dolna }\end{array}$ & 0.00 & 0.16 & 0.00 & 0.00 & 19.27 & 0.51 & 0.00 & 1.06 & 3.01 & 1.11 & 0.00 & 0.00 & 0.39 & 0.00 & 0.00 \\
\hline Lesko & 0.00 & 0.10 & 1.21 & 22.58 & 0.00 & 32.88 & 6.21 & 0.22 & 1.60 & 1.91 & 1.76 & 1.16 & 0.01 & 1.98 & 4.38 \\
\hline Jankowce & 1.52 & 1.12 & 0.00 & 5.44 & 23.16 & 0.00 & 22.18 & 0.00 & 0.30 & 1.36 & 0.00 & 0.00 & 0.00 & 0.00 & 0.00 \\
\hline Glinne & 0.00 & 0.17 & 0.11 & 0.00 & 12.73 & 3.66 & 0.00 & 0.68 & 0.32 & 0.27 & 0.00 & 0.00 & 0.00 & 0.00 & 0.00 \\
\hline Manasterzec & 0.00 & 0.00 & 0.00 & 2.80 & 17.31 & 0.00 & 0.00 & 0.00 & 38.98 & 4.38 & 0.00 & 0.00 & 1.70 & 0.00 & 2.17 \\
\hline Łukawica & 0.00 & 0.39 & 0.00 & 1.66 & 6.20 & 0.70 & 0.25 & 1.66 & 0.00 & 0.38 & 0.00 & 0.00 & 0.33 & 0.00 & 0.00 \\
\hline Huzele & 0.16 & 0.42 & 0.00 & 0.00 & 81.79 & 0.00 & 0.13 & 0.00 & 1.00 & 0.00 & 1.94 & 0.25 & 0.00 & 0.09 & 0.37 \\
\hline Łączki & 0.00 & 5.38 & 0.20 & 0.00 & 19.72 & 0.10 & 0.20 & 0.00 & 0.00 & 4.46 & 0.00 & 3.02 & 0.00 & 0.00 & 0.55 \\
\hline Weremień & 0.00 & 0.00 & 0.00 & 0.00 & 12.06 & 0.23 & 0.00 & 0.00 & 0.00 & 0.00 & 1.75 & 0.00 & 0.00 & 0.00 & 0.00 \\
\hline $\begin{array}{l}\text { Bezmiechowa } \\
\text { Górna }\end{array}$ & 0.00 & 0.00 & 0.00 & 21.40 & $18.8 \mathrm{~s}$ & .00 & .15 & 6.61 & 4.87 & 2.17 & 0.00 & 0.00 & 0.00 & 0.00 & 0.00 \\
\hline Dziurdziów & 0.00 & 14.68 & 0.00 & 0.00 & 6.38 & 3.87 & 0.00 & 0.00 & 0.00 & 0.00 & 0.00 & 0.00 & 0.00 & 0.00 & 0.00 \\
\hline Postołów & 0.00 & 0.00 & 0.35 & 0.00 & 54.23 & 0.76 & 0.00 & 0.00 & 0.00 & 0.57 & 0.00 & 0.00 & 0.00 & 0.00 & 0.00 \\
\hline
\end{tabular}

Source: own study. 


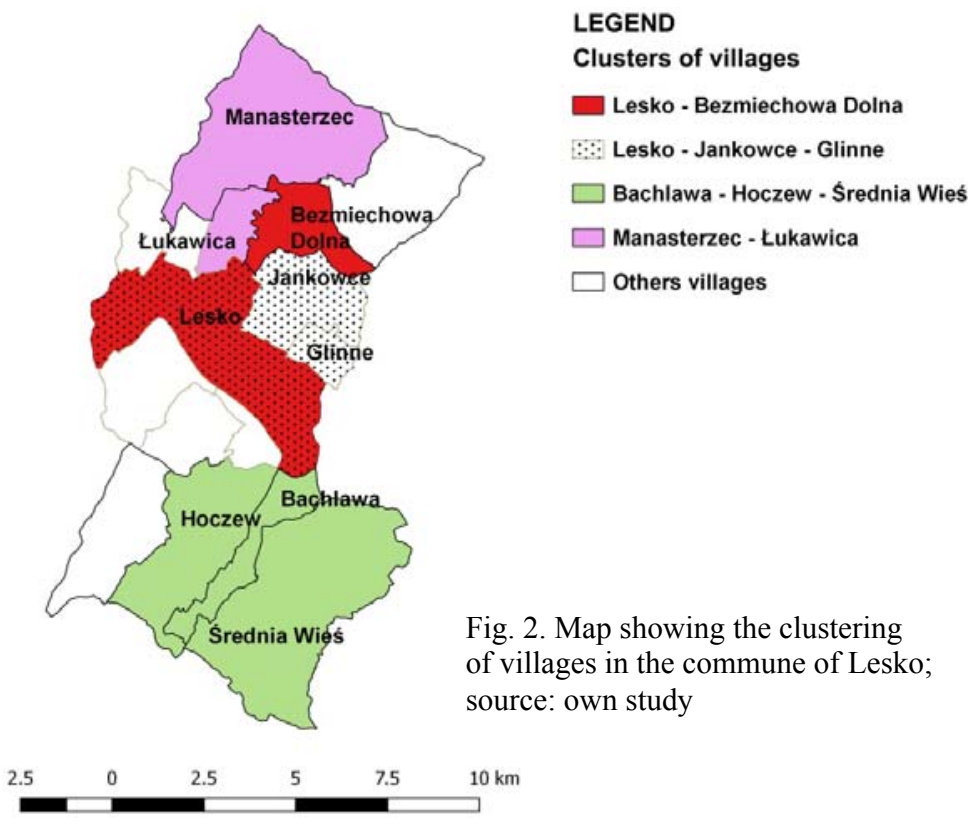

analysed in terms of the area occupied by non-resident-owned plots and the number of owners and plots, is extensive. According to the analysed data, $2,273.9732$ hectares of land in the commune of Lesko, i.e. $50.1 \%$ of privately owned plots, belong to local and out-ofvillage non-residents. This area is divided into 4155 cadastral plots, which represent $40.6 \%$ of all parcels in the private sector. The analysis regarding the elimination of the external patchwork of land ownership in the villages of the commune of Lesko shows that there are interrelationships among the individual villages. These investigations helped us determine between which cadastral communities land should be exchanged first. The main causes of land fragmentation in the investigated area are migration of inhabitants to other cities in search of work, as well as marriages, and

be analysed. In the present study, a separate matrix was created for all the data. The results obtained in the matrix are ordered so that the highest values are situated along the diagonal, which allows one to identify areas of the greatest concentration of checkerboarded farmland With a structured matrix, one can determine the degree of fragmentation and the territorial extent of the patchwork of land intermingled for pairs of villages and subsets of villages, but also for an entire commune. This method of analysing patchwork patterns of land ownership provides an easy and transparent way of determining the degree of fragmentation of farmland [NoGA 2001]. The results of the study are shown in Table 8 . The analysis revealed the existence of a defective, external patchwork of fields in the commune of Lesko. To boost the development of agricultural production and improve the farmers' working and living conditions, land must be exchanged between local and out-of-village nonresidents.

The analysis showed that there were links among the villages of the commune. The results are shown in Table 8 and, in a graphic form, in Figure 2. The first step towards amending the faulty structure of land ownership in the commune of Lesko should be to offer landowners a land exchange program which would bring fields closer to their place of residence. Such a solution would significantly improve the structure of the area under study and the living and working conditions of the inhabitants of this area. Cultivation of land in this place would become easier and more efficient with reduced costs and time of travel to and from a field.

\section{CONCLUSIONS}

The present study shows that the external patchwork of land ownership in the commune of Lesko, inheritance of land. The study demonstrated that a large part of land in the commune of Lesko is owned by urban residents. In the case of parcels belonging to non-resident owners who live in cities, a thorough analysis must first be conducted regarding the area of these plots and their location. If they are located in a built-up and urbanized area or are recreational plots, they should not be included in an exchange program. If, however, they are part of a defective land ownership structure (an external patchwork of fields), they should be "re-located", in the process of comprehensive land consolidation, so that they are situated closer to owners who would want to lease them. Under no circumstances should consolidation programs encourage owners from towns and cities to sell farmland.

\section{REFERENCES}

Balawejder M., Bielska A., Cymerman R., Gniadek J., Mazur A., OgryzeK M., Pijanowski J. M., SobolewSKa-Mikulska K., StańczUK-GaŁWiaczeK M., TASZAKOWSKI J. 2015. Współczesne scalenia gruntów w kształtowaniu granic rolniczej przestrzeni produkcyjnej [Modern land consolidation in shaping the boundaries of agricultural production space]. Ed. K. Sobolewska-Mikulska. T. 1. Ser. Monografie Naukowe Wydziału Geodezji i Kartografii Politechniki Warszawskiej „Geodezja i Kartografia”. Warszawa. OW PW pp. 117.

BALAWEJDER M., NogA K. 2016. The influence of the highway route on the development of patchwork of plots. Journal of Water and Land Development. No. 30 p. 3-11.

DUDZIŃSKA M. 2012. Szachownica gruntów rolnych jako czynnik kształtujący przestrzeń wiejską [Patchwork of fields as a factor which affects rural space]. Infrastruktura i Ekologia Terenów Wiejskich. Nr 2 p. 45-56.

KOCENT-ZIELIŃSKI W. 1907. Jak usuwać szachownice i przeprowadzać kolonizację gruntów [How to eliminate a patchwork of plots and colonize land]. Warszawa pp. 64. 
LEŃ P. 2009. Rozmiary gruntów różniczan i możliwości ich likwidacji (na przykładzie wsi w powiecie Brzozów, województwo podkarpackie). W: XVII Ogólnopolska Konferencja „Nowe tendencje w teorii i praktyce urządzania obszarów wiejskich” na temat „Rozwój obszarów wiejskich - stan obecny i perspektywy" [The size of the contribution of land belonging to non-residents and the possibility of eliminating faulty land ownership: the example of villages in the district of Brzozów in Podkarpackie Province. In: XVII National Conference "New trends in the theory and practice of rural management" on "Rural development - present condition and prospects"]. Puławy 24-26.06.2009 p. 73-78.

LEŃ P. 2012. Prawidłowości w rozmiarze występowania gruntów różniczan zamiejscowych na przykładzie wsi w powiecie Brzozów [Patterns in the size of the contribution of plots belonging to out-of-village owners: the example of villages in the district of Brzozów]. Infrastruktura i Ekologia Terenów Wiejskich. Nr 1 p. 137145.

LeŃ P., DZhyadosh D., Kovalyshyn O. 2015a. Vykorystannyaprohramy Quantum GIS pidchasanalizuprostorovoyi struktury sela Ol'Shanytsya [Use of Quantum GIS in the analysis of the spatial structure of Olszanica village]. Ser. Ekonomika APK. No. 22 (2) p. 151-158.

LeŃ P., MATYSEK I., Kovalyshyn O. 2015b. Dimensions of plots belonging to out-of-village owners in the village of Będziemyśl, commune of Sędziszów Małopolski. Geomatics and Environmental Engineering. Vol. 9. No. 2 p. 63-70.
LeŃ P., Mika M., WóJCIK-LeŃ J. 2016. Estimation of the size of the external land patchwork based on test areas in Podkarpackie Voivodship in Poland. Geomatics, Land Management and Landscape. No. 1 p. 65-74.

NogA K. 1977. Analiza międzywioskowej szachownicy gruntów na przykładzie wsi położonych $\mathrm{w}$ górnym dorzeczu Soły [An analysis of an inter-village patchwork of plots: The example of villages located in the upper basin of the river Soła]. Zeszyty Naukowe AR Kraków. Z. 133. Sesje Naukowe. Nr 7 p. 154-170.

NoGA K. 1985a. Możliwości likwidacji szachownicy zewnętrznej gruntów [The possibility of liquidation of external patchwork of plots]. Prace Naukowe Politechniki Warszawskiej. Ser. Geodezja. Nr 26 p. 231-237.

Noga K. 1985b. Problematyka likwidacji międzywioskowej szachownicy gruntów. W: Nowe tendencje scalania gruntów indywidualnych w terenach wyżynnych, górzystych i górskich [The issue of liquidation of an inter-village patchwork of plots. In: New trends in land consolidation in individual upland, mountain and mountain]. T. I. Puławy. IUNG p. 143-166.

NoGA K. 2001. Metodyka programowania i realizacji prac scalenia i wymiany gruntów w ujęciu kompleksowym. [A comprehensive approach to methods of programming and implementing land consolidation and exchange interventions]. Kraków. AR pp. 88.

Starostwo Powiatowe w Lesku undated. Dane ewidencji gruntów i budynków [Land and building registration data]. Wydział Geodezji, Katastru i Nieruchomości.

\section{Przemysław LEŃ}

\section{Rozmiary zewnętrznej szachownicy gruntów wyznacznikiem pilności wykonywania prac scalenia i wymiany gruntów na przykładzie gminy Lesko}

\section{STRESZCZENIE}

Szachownica gruntów jest jednym z istotnych czynników wywierających ujemny wpływ, zarówno na organizację, jak i poziom produkcji rolniczej. Nadmierna fragmentacja zmniejsza intensywność prac oraz zwiększa koszty produkcji rolniczej, co skutkuje coraz niższymi dochodami. W pracy przedstawiono dane dotyczące gruntów różniczan, tj. ich liczby, zajmowanej przez nie powierzchni oraz liczby działek. Obszar badań obejmuje gminę Lesko, w której skład wchodzi 15 obrębów ewidencyjnych. Badania wykonano sposobem tablic szachownicowych, umożliwiających określenie rozmiarów występowania różniczan zamiejscowych i miejscowych. Takie ujęcie pozwala na ustalenie wymiany gruntów między nimi oraz ich likwidację w procesie prac scalenia i wymiany gruntów.

Słowa kluczowe: obszary wiejskie, różniczanie, scalenie i wymiana gruntów, szachownica gruntów 